\title{
Echocardiographic and Doppler Aspects of Chronic Pulmonary Heart. About 11 cases
}

Bani $\mathrm{Am}^{1 *}$, Bidounga $\mathrm{Mm}^{2}$, Makele $\mathrm{C}^{3}$, Gondolat-Bompempe $\mathrm{PN}^{4}$.

${ }^{1}$ Service de cardiologie. Hôpital général de Loandjili

${ }^{2}$ Service de radiologie. Hôpital général de Loandjili.

${ }^{3}$ Service de réanimation médicale. Hôpital général de Loandjili.

${ }^{4}$ Service de pneumologie. Hôpital Adolphe SICE.

*Corresponding Author: Docteur BANI Aloïse Macaire, cardiologue. Service de cardiologie de l'hôpital général de Loandjili. Pointe- Noire ; République du CONGO (BRAZZAVILLE) B.P 8122

Received Date: July 30, 2021; Accepted Date: September 29, 2021; Published Date: October 08, 2021

Citation: Bani Am, Bidounga Mm, Makele C, Gondolat-Bompempe PN. (2021) Echocardiographic and Doppler Aspects of Chronic Pulmonary Heart. About 11 cases. J. Clinical Cardiology and Cardiovascular Interventions, 4(16); Doi:10.31579/2641-0419/199

Copyright: () 2021 Docteur BANI Aloïse Macaire, This is an open-access article distributed under the terms of the Creative Commons Attribution License, which permits unrestricted use, distribution, and reproduction in any medium, provided the original author and source are credited.

\begin{abstract}
:
Pulmonary chronic heart (CPC) is an enlargement associated or not with dilation of the right ventricle.

Objective: To recall the echocardiographic-Doppler aspects essential for the screening of pulmonary chronic heart.

Patients and method: Retrospective study carried out between January 2009 and April 2019 interesting the cases of pulmonary chronic heart.

Results: out of 124 cases of pulmonary chronic heart, 11 cases were included. These were four men and 7 women with a mean age of $63 \pm 19$ years (range: 20-84 years). The radiological and electrical semiology of pulmonary chronic heart was found, lacking specificity and sensitivity. Dilation of the right heart chambers, dyskinesia of the interventricular septum and hypertrophy of the free wall of the right ventricle $>5 \mathrm{~mm}$ were observed. The mean maximum velocity of tricuspid insufficiency on continuous Doppler was $4.6 \pm 1.32 \mathrm{~ms} / \mathrm{s}$ (Extremes: $3.59-7.58 \mathrm{~m} /$ s) and the mean dilation of the inferior vena cava was $23.2 \pm 3.9 \mathrm{~mm}$ (Extreme: $21.2-27 \mathrm{~mm}$ ).
\end{abstract}

Conclusion: $\mathrm{CPC}$ is uncommon and predominant in women. The EKG and chest X-ray are first-line exams without sensitivity or specificity. Screening for CPC is based on echocardiographic-Doppler criteria. The right cardiac catheterization remains the key examination.

Keywords: Screening; pulmonary chronic heart; additional examinations

\section{Introduction:}

Chronic cor pulmonale (CPC) is the set of structural modifications of the heart characterized by right cardiac hypertrophy, with or without dilation, relating to an increase in resistance in the small circulation of pulmonary origin, and unrelated to heart disease. left ventricular.

The right ventricle (RV) and pulmonary vasculature are accessible on echocardiography. In this regard, the most illustrative changes affecting this low-pressure vascular system are observed in adults with pulmonary arterial hypertension $(\mathrm{PAH})$.

In isolation or in combination, the occurrence of CPC is multifactorial and its pathophysiology is dominated by pre-capillary PAH syndrome.
In France, the literature on CPC is abundant, but remains old [1-3]. In subSaharan Africa, CPC is poorly observed in cardiology, unlike pneumology because of its attachment to chronic obstructive pulmonary disease (COPD) and other pulmonary diseases, in particular sleep apnea syndromes, and mixed syndromes (obstructive and restrictive) [4,5].

In practice, the problems posed by $\mathrm{CPC}$ are multiple: On the one hand, the therapeutic management is dependent on the aetiology of the five clinical forms of $\mathrm{PAH}$, and requires the holding of multidisciplinary consultations involving cardiologists, pulmonologists, internists, psychologists and physiotherapists. On the other hand, the chronic deficit of the technical platform that our countries encounter, the conception of a long-lasting affection in our traditional societies, high therapeutic costs 
and the lack of catheterization rooms mean that non-invasive examinations such as that Doppler echocardiography or chest CT become essential in the screening, monitoring and etiological research of CPC.

Blood gases, cardiac catheterization, pulmonary perfusion scintigraphy, magnetic resonance angiography with injection of the para-magnetic contrast product are very interesting complementary examinations, but inaccessible, or even absent in our context, whereas imaging medical plays a key role in the diagnosis and evaluation of PAH [6].

Thus, by carrying out this work, our objective is to recall the advantages of echocardiographic-Doppler criteria essential for the screening and monitoring of CPC in our context.

\section{I- Patients and Method:}

This is a retrospective study carried out in the cardiology department of the Loandjili general hospital in Pointe-Noire in Congo-Brazzaville between January 2009 and April 2019, i.e. 10 months and 3 months.

We analyzed the files of patients hospitalized for exclusive right heart failure related to CPC. We found a history of COPD, electroencephalogram, HIV serology, and chest computed tomography in the files.

The selected records should include a chest x-ray (frontal and lateral), a surface electrocardiogram, a Doppler echocardiography and a laboratory test (blood count, hemoglobin electrophoresis, and HIV serology). Blood gases being unavailable in our context.

The radiological criteria used were hilar dilation of the pulmonary arteries $>17 \mathrm{~mm}$, convexity of the left middle arch, infundibular protrusion, anterior detachment of the RV and the presence of pulmonary fibrosis or pulmonary emphysema. Cardiomegaly was defined when the cardiothoracic index $>0.5$.
The electrical criteria used were the $>+110^{\circ} \mathrm{QRS}$ axis, the existence of a deep S wave in V5-V6; a W morphology of QRS, the presence of a predominant $\mathrm{R}$ wave in $\mathrm{V} 1-\mathrm{V} 3$, a $\mathrm{p}>2.5 \mathrm{~mm}$ wave in $\mathrm{D} 2$, QR aspects in V1, S1Q3, RSR 'in V1-V2, QS in V1- V2, S1S2S3 in the peripheral leads, as well as a low voltage in the same leads.

The echocardiographic criteria used were hypertrophy of the free wall of the $\mathrm{RV}>5 \mathrm{~mm}$, maximum continuous Doppler velocity of tricuspid insufficiency $>3.5 \mathrm{~m} / \mathrm{s}$, dilation of the inferior vena cava $>21 \mathrm{~mm}$, paradoxical kinetics of the interventricular septum, the existence of pericarditis and dilation of the right cardiac chambers (systolic tele surface of the right atrium $>14 \mathrm{~cm} 2$; tele diastolic diameter of the RV > $23 \mathrm{~mm}$ in movement time).

We excluded all cases of constrictive endomyocardial fibrosis, uremic heart, chronic constrictive pericarditis, arrhythmogenic RV dysplasia, myocardial infarction, acute pulmonary embolism, severe mitral stenosis and all right valve involvement acquired from rheumatic origin.

The study variables were epidemiological, radiological, electrical and echocardiographic.

\section{Results:}

Of the 852 hospitalized heart failure cases, 124 cases were labeled exclusive right heart failure presumed to be related to CPC, and among which 11 cases met our inclusion criteria, for a relative frequency of $1.29 \%$

\section{IIA Epidemiological aspects:}

There were four cases of men and 7 cases of women. The mean age of the patients was $63 \pm 19$ years (range: 20 -86 years). Six patients were between 63-83 years old. In this age group there were four men and two women. Two patients were between 84-104 years old. Two other patients were between 42-62 years old. Finally, a recent childbirth patient was between 0-20 years old. Figure 1 shows the distribution of patients by age and sex.

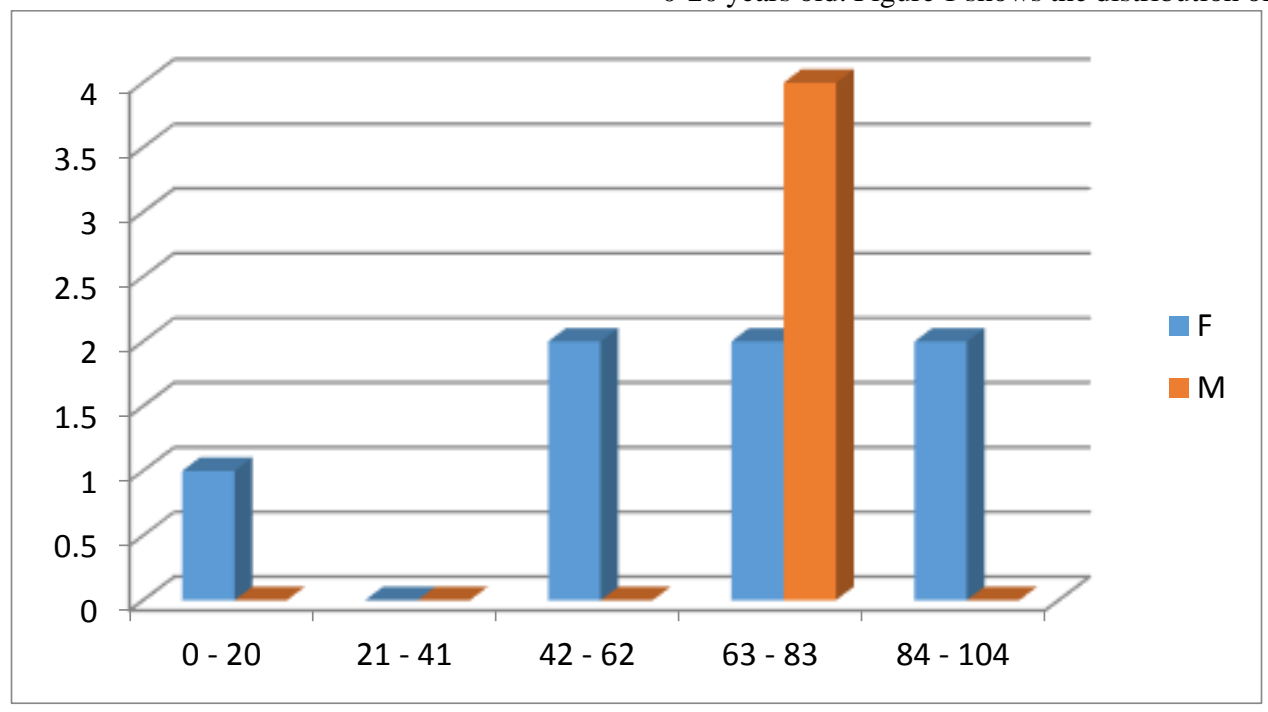

Figure 1: Répartition des patients selon l'âge et le sexe.

\section{IIB}

\section{Aspects radiologiques :}

La cardiomégalie était observée chez tous les patients avec un index cardio thoracique moyen à $61,2 \pm 5,8 \%$ (extrêmes : 55-72\%). 10 patients avaient une dilatation des artères pulmonaires. Neuf patients présentaient une convexité de l'arc moyen gauche et un décollement du VD. La fibrose pulmonaire était observée chez deux patients et l'emphysème pulmonaire touchait un patient. Le tableau I représente la répartition des patients selon l'aspect radiologique et les figures 2-3 illustrent les différentes images radiologiques (d'emphysème pulmonaire, de fibrose pulmonaire et de cardiomégalie avec convexité de l'arc moyen gauche associé à un œdème pulmonaire interstitiel). 


\begin{tabular}{|l|l|l|}
\hline ASPECTS RADIOLOGIQUES & Nombre & $\%$ \\
\hline Dilatation des artères pulmonaires & 10 & 91 \\
\hline Convexité de l'arc moyen gauche & 9 & 81,9 \\
\hline Saillie infundibulaire & 1 & 9,1 \\
\hline Décollement du ventricule & 9 & 81,9 \\
\hline Fibrose pulmonaire & 2 & 18,2 \\
\hline Emphysème pulmonaire & 1 & 9,1 \\
\hline Cardiomégalie & 11 & 100 \\
\hline
\end{tabular}

Table 1: Répartition des patient's selon les aspects radiologiques

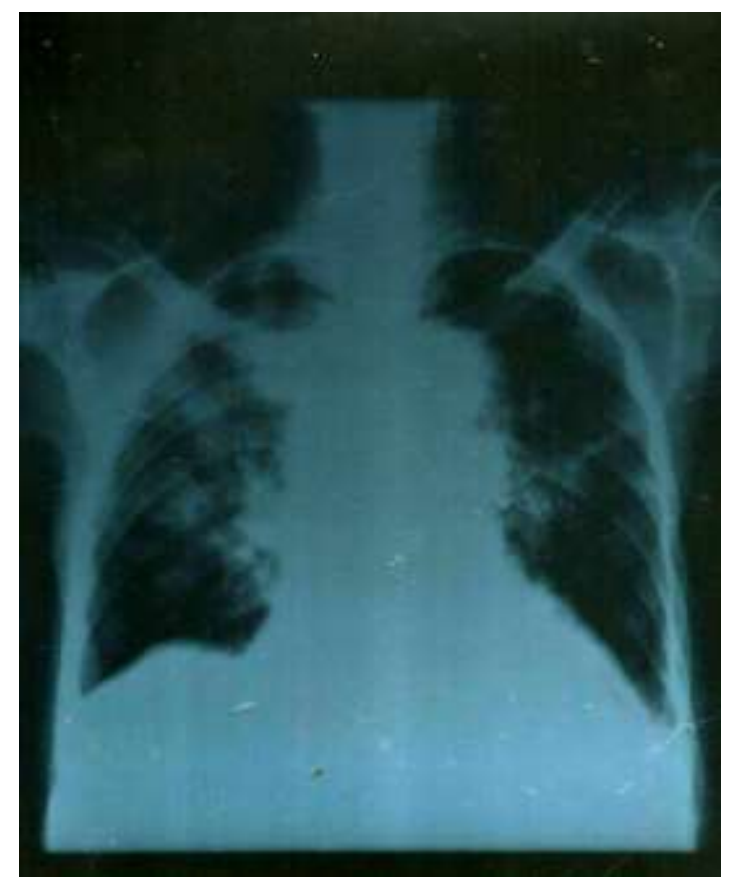

Figure 2 : Radiographie thoracique (face) d'une patiente de 86 ans objectivait un oedème pulmonaire interstitiel, une rectitude du bord droit du cœur, une convexité de l'arc moyen gauche, une dilatation des artères pulmonaires et une cardiomégalie avec index cardio-thoracique à 0,55.

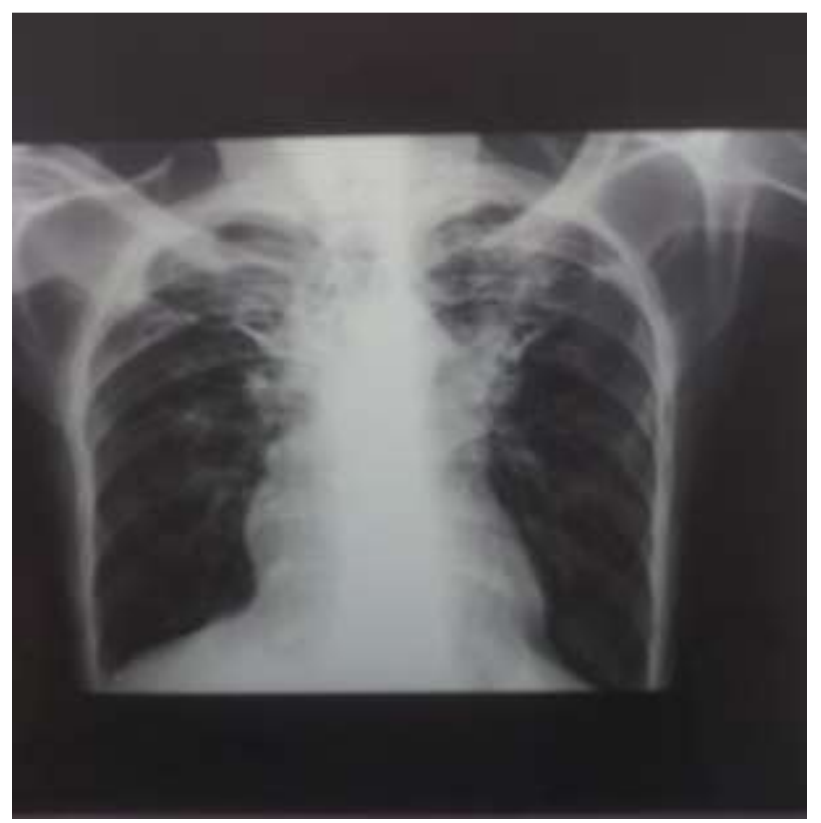

Figure 3: Radiographie thoracique (face) d'un patient de 63 ans montrait des opacités infiltratives hilo apicales bilatérales avec images aériques cerclées apicale bilatérales compatibles aux bulles d'emphysème séquellaire d'une bacillose pulmonaire. On notait également un émoussement des culs de sac costo-diaphragmatiques droit, et une cardiomégalie avec index cardio-respiratoire à 0,5. 


\section{IIC Aspect électriques :}

L'axe des $Q R S$ était au- delà de $+110^{\circ}$ chez tous les patients. 10 patients avaient un aspect RSR'. L'onde R était prédominante en V1-V3 chez neuf patients. Sept patients présentaient une onde $\mathrm{P}>2,5 \mathrm{~mm}$ en D2. Six patients avaient un aspect QS. Les aspects QR en V1 et S1Q3 étaient observés chez trois patients. Deux patients présentaient un aspect en W et enfin le bas voltage des QRS existait chez un patient. Plusieurs de ces aspects électriques pouvaient s'observés chez un patients comme le mentionne la figure 4. Le tableau II montre la répartition des patients selon les aspects électriques.

\begin{tabular}{|l|l|l|}
\hline ASPECTS ELECTRIQUES & NOMBRE & $\%$ \\
\hline Axe QRS à droite & 11 & 100 \\
\hline Aspect QR en V1 & 3 & 27,3 \\
\hline Onde R prédominant en V1-V3 & 9 & 81,9 \\
\hline Aspect S1Q3 & 3 & 27,3 \\
\hline Aspect RSR' & 10 & 91 \\
\hline Aspect QS & 6 & 54,6 \\
\hline Aspect en W & 2 & 18,2 \\
\hline Onde S prédominant en V5-V6 & 5 & 45,5 \\
\hline Onde P>2,5 mm en D2 & 7 & 63,7 \\
\hline Bas voltage périphériques & 1 & 9,1 \\
\hline
\end{tabular}

Table 2: Répartition des patient's selon les aspects radiologiques.

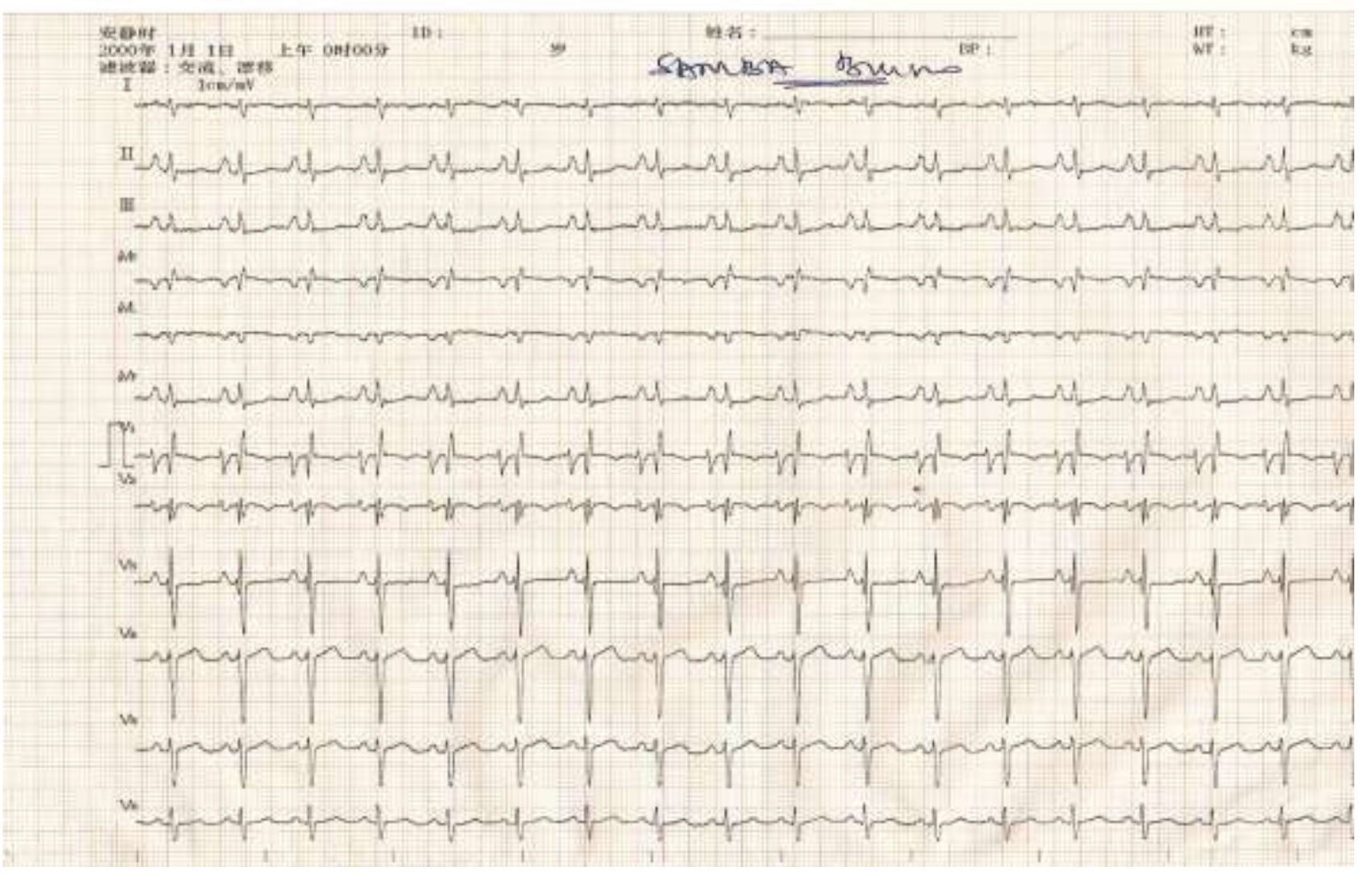

Figure 4 : Electrocardiogramme de surface d'un patient de 63 ans en rythme sinusal, avec une fréquence cardiaque à 100 battements par minute illustrait une onde P pulmonaire, un micro voltage dans les dérivations périphériques, un axe des QRS à droite, et un bloc de branche droite complet.

\section{IID Aspects échocardiographiques-Doppler :}

IID1 Vélocité de l'insuffisance tricuspidienne en Doppler continu (V. max IT):

La V. max de l'IT moyenne était de 4,6 $\pm 1,32 \mathrm{~m} / \mathrm{s}$ (extrêmes : 3,59-7,58 $\mathrm{m} / \mathrm{s}$ ). Huit patients avaient une V. max de l'IT comprise entre 3,5-4,5 m/s. Respectivement, chaque patient présentait des V. max de l'IT comprise entre 4,6-5,6 m/s, entre 5,7-6,7 m/s, et enfin entre $6,8-7,8 \mathrm{~m} / \mathrm{s}$. Le tableau III représente la répartition des patients selon la V. max de l'IT. 


\begin{tabular}{|l|l|l|}
\hline V max IT & Nombre & $\%$ \\
\hline $3,5-4,5$ & 8 & 73 \\
\hline $4,6-5,6$ & 1 & 9,1 \\
\hline $5,7-6,7$ & 1 & 9,1 \\
\hline $6,8-7,8$ & 1 & 9,1 \\
\hline Total & 11 & 100 \\
\hline
\end{tabular}

Table 3: Répartition des patients selon la V. max IT.

\section{IID2 Dilatation de la veine cave inférieure (VCI) :}

La VCI mo yenne était de 23,2 $\pm 3,9 \mathrm{~mm}$ (extrêmes : 21,2-30 mm). Respectivement cinq patients avaient des VCI comprises entre $21-23 \mathrm{~mm}$ et 24-27 mm. Enfin, un patient hyper tabagique avait une VCI entre 28$30 \mathrm{~mm}$. Le tableau IV représente la répartition des patients selon la dilatation de la VCI.

\begin{tabular}{|c|c|c|}
\hline VCI $(\mathbf{m m})$ & Nombre & \% \\
\hline $21-24$ & 5 & 45,5 \\
\hline $25-28$ & 5 & 45,5 \\
\hline $29-32$ & 1 & 9,1 \\
\hline Total & 11 & 100 \\
\hline
\end{tabular}

Table 4: Répartition des patient's selon la dilatation de la VCI

\section{IID3 Existence d'une HTAP :}

L'hypertrophie de la paroi libre du VD et la dilatation des cavités cardiaques droite était retrouvée chez tous les patients. Neuf patients présentaient une paradoxalité du septum inter ventriculaire et huit patients avaient une péricardite. Le tableau $\mathrm{V}$ représente la répartition des patients selon l'HTAP et la figure 6 représente les aspects échocardiographiques du CPC.

\begin{tabular}{|l|l|l|}
\hline HTAP & Nombre & $\%$ \\
\hline SIV paradoxal & 9 & 81,9 \\
\hline Epanchement péricardique & 8 & 72,8 \\
\hline Dilatation cavités cardiaques droite & 11 & 100 \\
\hline Hypertrophie paroi libre VD & 11 & 100 \\
\hline
\end{tabular}

Table 5: Répartition des patients selon l'HTAP.

\section{Discussion:}

Our job suffers from a weakness in recruitment. It can be explained by the abandonment of many cases labeled CPC without specific ethical bases (These were former patients labeled known CPC, who decompensated in the waning of a maintenance therapeutic discontinuation, influenza infectious syndromes or deviation). In addition, some of our files that did not meet the criteria for inclusion were simply excluded.

$\mathrm{CPC}$ is an enlarged dilation of the right heart after PAH. It is uncommon and mainly affects older people [5,7]. Our female predominance is similar to other series $[5,8]$. It may be justified by the presence of pulmonary plexiform arteriopathy (an enlargement of the media of the pulmonary arteries of small caliber, an intimal concentric onion bulb fibrosis and plexiform lesions). This histological type is found preferentially in women in the order of 28 to $71 \%$ and is thought to favor the onset of CPC [9]. The hypotheses according to which pregnancies, hormonal contraception, embolizations by micro thrombi of pelvic origin or menstrual periods, have been mentioned as factors favoring CPC [10]. The male sex is struck by predilection because of smoking, professions exposed to bad weather and those conducive to pneumoconiosis.

In its initial phase, CPC progresses slowly with emphysematous and catarrhal flares. These flare-ups progress between 5, 10, 15, 20 years or even more during which no specific functional sign of CPC is evident. This progressive type can explain its prevalence in pneumologic environment and at advanced ages. Chest radiography usually illustrates an increase in the volume of the trunk and proximal pulmonary arteries, cardiomegaly, interstitial syndrome or pulmonary edema as noted in the literature [11] . All these radiological signs are inconstant and do not claim to be diagnosed with CPC. This radiological examination lacks sensitivity and specificity [12]. The electrical signs gradually set in with the development of CPC. The initial period is characterized by right ventricular hypertrophy (HVD) which allows diagnosis in $1 / 3$ of cases. In the stage of right ventricular failure, HVD is still present, to varying degrees. It can be accompanied by Q waves or QS aspect in the right precordial leads, or else of QR aspect in D2, D3 and aVF thus translating the recording of the intracavitary potentials via a right atrium. strongly dilated. The HVD is characterized by a large R in V1. The rhythm remains sinus and right atrial enlargement is common. The low voltage of QRS in peripheral leads is related to COPD, and frequently the axis of QRS is deviated to the right. The QRS complex can take many forms, of the S1Q3 type (dextro position) in standard leads or of the S1S2S3 type. Pulmonary emphysema may also be able to significantly increase the resistance of the tissues interposed between the heart and the electrodes [7,11]. These different electrical signs also lack sensitivity [12]. Doppler 
echocardiography is unquestionably the preferred investigation in CPC. It allows repeated quantitative estimation of pulmonary arterial pressure [13]. This tool is used in the detection and monitoring of CPC. There are two echocardiographic-Doppler methods that can be combined. This particularly concerns the measurement of V. max IT and the acceleration time in the pulmonary arterial trunk. V. max IT is essential for the diagnosis of CPC, however the acceleration time in the pulmonary artery is less used in practice [13,14]. This V. max IT was recently validated in PAH as a building block of a CPC screening algorithm [14]. V. max IT over $3.5 \mathrm{~m} / \mathrm{s}$ is associated with the vast majority of anterior wall hypertrophy of the RV and dilation of the IVC. These two signs can only be found in CPC [15]. The echocardiography essentially finds dilation of the right heart chambers, a paradoxical interventricular septum and pericarditis. Thus, this morphological and hemodynamic information obtained echocardiographically requires confirmation by right cardiac catheterization. The latter is par excellence the key examination of the diagnosis of CPC, but the deficit in the catheterization room remains a major handicap in our context. Chest CT angiography looks for evidence of the aetiological diagnosis of CPC, and its synchronization with the EKG can assess the impact of PAH on right ventricular systolic function. This ventricular function collapses in PAH, but the correlation between pulmonary arterial pressure and ejection fraction of the RV is not linear [17]. This argument has been a criterion of little enthusiasm on our part in evaluative research of systolic function of the RV. In addition, CT angiography does not protect the patient from harmful radiation [18]. Currently, the CT scan does not allow the etiological determination of all CPCs. Thus, some authors prefer ventilation / perfusion lung scintigraphy in hypoxic forms [16]. Magnetic resonance imaging (MRI) of the chest, particularly magnetic resonance angiography, is very interesting. This examination allows the study of pulmonary vascularization, but the abnormalities found are substantially comparable to those obtained with conventional angiography up to the segmental level, and they are insufficient at the sub-segmental level [19].

\section{Conclusion:}

$\mathrm{CPC}$ is uncommon and the predominance of women is notable. Chest $\mathrm{X}$ rays and EKGs are first-line exams that lack sensitivity and specificity. Doppler echocardiography remains essential in the detection and followup of CPC. Right cardiac catheterization suffers from the lack of available rooms. The CT angiography is of considerable interest but exposes the dangers of radiation. Finally, the other cardiological explorations are unavailable in our context.

\section{References:}

1. LENEGRE J, MAURICE P, SCEBAT L. Les stades initiaux du cœur pulmonaire chronique. Acta Cardiologica 1954 ; 9(4) : 314-42.

2. TOURMAIRE A, TARTULIER M, BLUM J et al. Le cœur pulmonaire chronique. Expansion scient. Franç. Edit. 1964.

3. BROUSTET P, BRICAUD H, CABANIEU G. Le cœur pulmonaire chronique. Paris, 1954, Baillère édit.

4. MACHIHUDE P, YAOVI A, SOULEMANE P, SOODOUGOUA B et al. Epidémiologie et étiologies des insuffisances cardiaques à Lomé. Pan Afr Med J 2014; 18:183.
5. DAMOROU F, PESSINABA S, YAYEHD K, BONSA NS et al. Le cœur pulmonaire chronique. A propos de 35 cas colligés à la clinique cardiologique du CHU Campus de Lomé. A JOL 2009; 11:2.

6. SANCHEZ O, REVEL MP, COUCHON S, MEYER G. Imagerie de l'hypertension artérielle pulmonaire. Rev Mal Resp 2007 ; 24 :155-89.

7. TOURE MK, DAO MY, DIALLO BA. Le point sur le Cœur pulmonaire chronique à Bamako. A propos de 22 cas. Med d'Afr Noire 1983, 40 :234-36.

8. RICH S, DANTZKER DR, AYRES SM et al. Primary pulmonary hypertension. A national prospective study. Ann Intern Med 1987, 107:216-223.

9. BJORNSSON J, EDWARDS WD. Primary pulmonary hypertension: a histopathologic study of 80 cases. Mayo Clin Proc, 1985, 60:16-25.

10. HUGUES JD, RUBIN LJ. Primary pulmonary hypertension. An analysis of 28 cases and a review of the literature. Medicine, 1986:56-72.

11. EKONO BITCHONG C, AZOUMBOU MEFANT T, ZE JJ, GWETH $\mathrm{N}$ et al. Cour pulmonaire chronique : Aspects morphologiques chez les patients non infectés par le VIH en décompensation inaugurale à Yaoundé. A JOL 2009; 11:2.

12. OSWALD-MAMMOSSER M, OSWALD T, NYANKIYE E, DICKELE MC et al. Non invasive diagnosis of pulmonary hypertension in chronic obstructive pulmonary disease: comparison of ECG, radiological measurements, echocardiography and myocardial scintigraphy. Eur J Respir Dis 1987; 71:419-29.

13. NAEIJER R, TORBICKI A. More on the non invasion diagnosis of pulmonary hypertension: Doppler echocardiography revisited. Eur Respi J 1995;8:1445-9.

14. HACHULLA E, GRESSIN V, GUILLEVIN L, CARPENTIER $\mathrm{P}$ et $a l$. Early detection of pulmonary arterial hypertension in systemic sclerosis: a French nationwide prospective multicenter study. Arthritis Rheum 2005; 52:3792-800.

15. KASPER W, GEIBEL A, TIEDE $\mathrm{N}$ et al. Distinguishing between acute and subacute massive pulmonary embolism by conventional and Doppler echocardiography. $\mathrm{Br}$ Heart $\mathrm{J}$ $1993 ; 70: 352-6$

16. SZTRYMF B, MONTANI D, SIMONNEAU G, HUMBERT $M$. Prise en charge diagnostique et thérapeutique de l'hypertension artérielle pulmonaire. Réanimation 2007; 16: 294-301.

17. BRENT BN, BERGER HJ, MATTHAY RA, MAHLER D et coll. Physiologic correlates of right ventricular ejection in chronic obstruction pulmonary disease: a combined radionuclide and hemodynamic study. Am J Cardiol 1982; 50:255-62.

18. VONK-NOORDEGRAAF A, WOLFEREN SA, MARCUS JT, BOONSTRA A et al. Noninvasion assessment and monitoring of the pulmonary circulation. Eur Respir J 2005; 25:758-66.

19. KREITNER KF, LEY S, KAUCZOR HU, MAYER E et $a l$. Chronic thromboembolic pulmonary hypertension: pre and postoperative assessment with breath-hold MR imaging techniques. Radiology 2004, 232:535-43. 
(cc) (i)

This work is licensed under Creative Commons Attribution 4.0 License

To Submit Your Article Click Here: Submit Manuscript

DOI: $10.31579 / 2641-0419 / 199$
Ready to submit your research? Choose Auctores and benefit from:

$>$ fast, convenient online submission

$>$ rigorous peer review by experienced research in your field

$>$ rapid publication on acceptance

$>$ authors retain copyrights

$>$ unique DOI for all articles

$>$ immediate, unrestricted online access

At Auctores, research is always in progress.

Learn more https://auctoresonline.org/journals/clinical-cardiology-andcardiovascular-interventions 